Article - Biological and Applied Sciences

\title{
In Silico Target Identification and Validation for Antioxidant and Anti-inflammatory Activity of Selective Phytochemicals.
}

\author{
Shikha Rana ${ }^{1^{\star}}$ \\ https://orcid.org/0000-0003-1128-2480
}

\section{Savita Dixit ${ }^{1}$}

\section{Alok Mittal ${ }^{1}$}

${ }^{1}$ Maulana Azad National Institute of Technology, Chemistry Department, Bhopal, Madhya Pradesh, India.

Received: 2019.01.29; Accepted: 2019.08.06.

*Correspondence: shikha11.rana@gmail.com; Tel.: +918109606168

\section{HIGHLIGHTS}

- Phytochemicals from six local grown plants (pomegranate, lemon, wheatgrass, papaya, sheesham leaves, turmeric leaves) were used for the present study.

- IMPPAT (a curative database) has been used for retrieving phytochemicals.

- Molecular docking is used against three enzymes involved in an antioxidant activity which includes Superoxide dismutase (SOD), Glutathione peroxidase (GPX) and Catalase (CAT).

- Cyclooxigenase-2 (COX-2) is tested for the anti-inflammatory activity of these phytochemicals.

- Punica Granatum (pomegranate), Citrus Limon (lemon), Triticum Aestivum (wheatgrass) and Carica Papaya (papaya) includes few phytochemicals which have shown promising binding affinities towards target proteins/enzymes.

Abstract: Phytochemicals present in plant extract include a number of biological active compounds which have shown promising antioxidant and anti-inflammatory activities in many animal studies. Present knowledge about the biochemical interactions of these compounds present in phytochemical extracts and target enzymes or proteins responsible for antioxidant and anti-inflammatory activity is limited. Present work is an attempt to identify and validate possible biological targets as enzymes or proteins involved in these targeted studies using molecular docking as computational method. IMPPAT: Indian 
Medicinal Plants, Photochemistry and Therapeutics (a curated database) has been used to retrieve various phytochemicals derived from selected plants which includes Carica papaya, Citrus limon, Curcuma longa, Dalbergia sissoo and Punica granatum. These phytochemicals are further evaluated using molecular docking against three enzymes involved in antioxidant activity which includes Superoxide dismutase (SOD), Glutathione peroxidase (GPX) and Catalase (CAT). Cyclooxigenase-2 (COX-2) has been tested for anti-inflammatory activity of these phytochemicals. Gliadin (Triticum aestivum), Tea Extract (Punica granatum), Hesperidin (Citrus limon), Terrestribisamide (Triticum aestivum), Vitamin P (Carica papaya) and 1,2,6-Trigalloylglucose (Punica granatum) are few phytochemicals which has shown promising binding affinities towards target proteins or enzymes Superoxide dismutase (SOD), Glutathione peroxidase (GPX) and Catalase (CAT) and cyclooxigenase-2 (COX-2).

Keywords: Target identification and validation; phytochemicals; antioxidant activity; antiinflammatory activity; molecular docking.

\section{INTRODUCTION}

Stems, leaves, and seeds of the papaya tree (Carica papaya) have medicinal properties along with the fruit itself [1]. It contains varies essential metabolites like the alkaloids, phenolic compounds, steroids, etc. which are responsible for its healing, antibacterial and anti-tumor activities [2]. The leaves of the plant are traditionally used for the treatment of malaria, dengue, and jaundice. The leaves and fruits contain carotenoids like beta-carotene and lycopene [3]. Citrus limon (Lemon) is rich in important metabolites like citric acid, flavonoids, and essential oils and most importantly phenolic compounds [4]. The most abundant flavonoids in lemons are flavanones ( $90 \%$ of total flavonoid content), which are weak acids and can be converted to isomeric chalcones in alkaline and acidic medium [5]. The major carotenoid in mature lemons is beta-cryptoxanthin and it is concentrated in the juice sacs and the outer peel [6].

The major metabolites of Curcuma longa are curcuminoids, constituting of curcumin (77\%), demethoxycurcumin (17\%) and bisdemethoxycurcumin (3\%) and volatile oils [7]. These compounds are responsible for the pharmacological activities of turmeric [8] like neutralizing the free radicals (ROS/RNS) [9] and inhibition of lipid peroxidation [10]. Curcumin also acts as an antioxidant by preserving the activities of enzymes like superoxide dismutase, glutathione peroxidase and catalase [11]. The root, bark, and stem of Punica granatum are used as astringents and anti-parasitic agents [12]. The Punica granatum plant has also shown evidence of having anti-tumor [13], antibacterial [14], antifungal [15] and anti-ulcer [16] activities. Ferric nitrilotriacetate (Fe-NTA) is a known cause of oxidative stress in the liver and kidneys. Its main mechanism of damage is lipid peroxidation. It also affects enzymes involved in glutathione metabolism and other enzymes having antioxidant actions. Pomegranate extract has been proved to lower the damage by its free-radical scavenging action [17]. Triticum aestivum (wheatgrass) is rich in vitamins, minerals, amino acids, and enzymes. It is generally used as a herbal 
medication in cases of thalassemia [18]. Hemolytic anemia is a condition caused by oxidative stress which causes hypoxia. The free radicals cause lipid peroxidation of the membrane lipids which causes rupture of the red blood cells. This can be controlled or prevented by intake of antioxidant supplements. Fresh juice of wheatgrass has been used as a supplement for several years [19]. All major parts of Dalbergia sissoo are used in medicinal preparations for the treatment of dysentery, skin diseases, bowel discomforts, leukoderma and ulcers amongst other diseases [20]. Dalbergia sissoo or Indian Rosewood has been widely studied for its flavonoid content which has high antioxidant activity.

Present work is an attempt to identify and validate biological targets which can be interacting with specific compounds present in phytochemical extracts of the plants discussed above. Based on their participation and literature available we have identified three proteins as a target for antioxidant activity offered by these plant extracts which include Superoxide dismutase (SOD), Glutathione peroxidase (GPX) and Catalase (CAT). Cyclooxygenase-2 (COX-2) has been identified and validated as a target for the antiinflammatory activity of these phytochemicals derived from selected plant extracts.

\section{MATERIAL AND METHODS}

Present studies include a collection of phytochemicals from selected plants, constructing a library, selection of proteins and enzymes identified as antioxidant and antiinflammatory targets and molecular docking studies of Phytochemical library with selected target proteins and enzymes. A graphical representation of the adopted methodology for present work has been produced in figure 1 below.

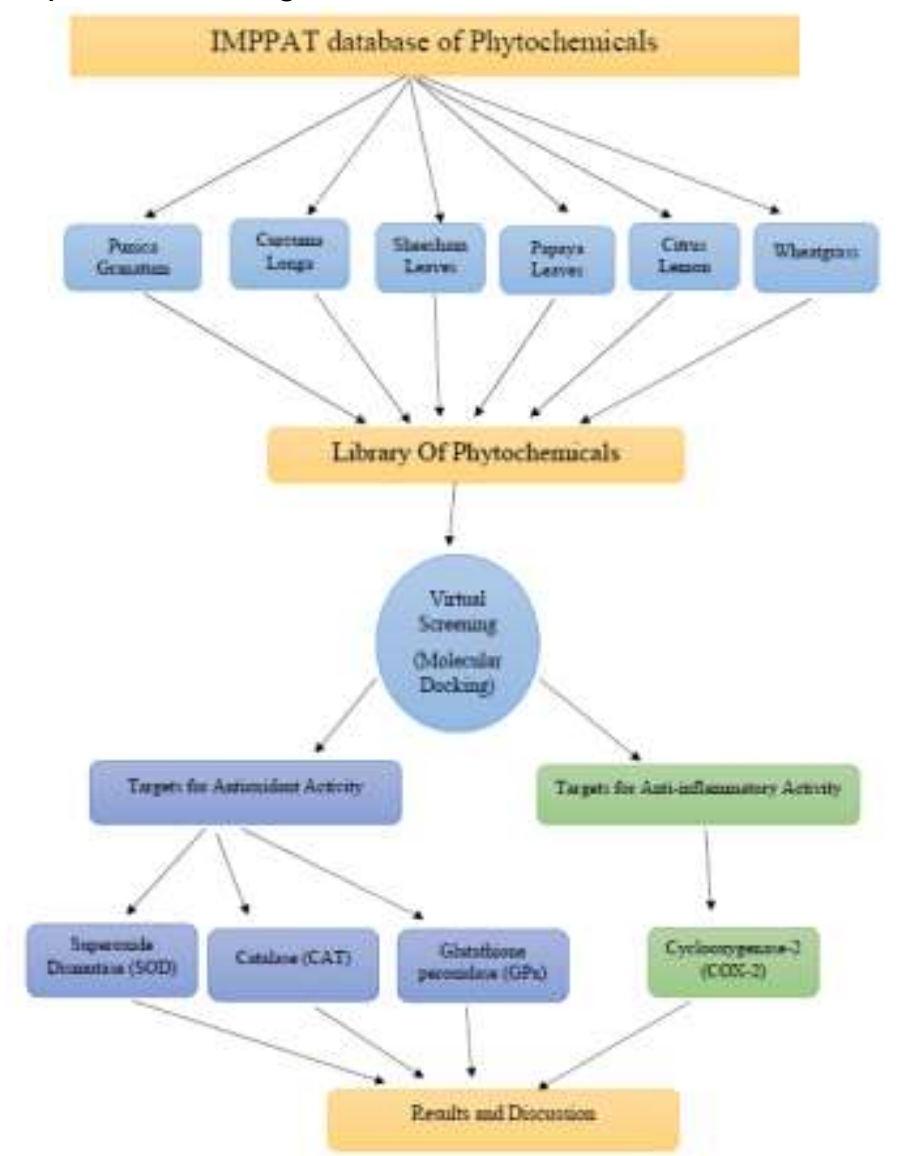

Figure 1. Graphical representation of the adopted methodology used targeted studies. 


\section{PHYTOCHEMICAL LIBRARY}

An online curated database has been used to collect reported phytochemicals from these five selected plants so far. IMPPAT: Indian Medicinal Plants, Photochemistry and Therapeutics (a curated database) is that online database where one can find a ready-touse list of phytochemicals based on plant selection. A complete list of phytochemicals from Carica Papaya, Citrus Limon, Curcuma Longa, Dalbergia Sissoo and Punica Granatum was retrieved from IMPPAT: Indian Medicinal Plants, Photochemistry and Therapeutics (a curated database).

\section{TARGET PROTEINS AND THEIR 3D STRUCTURES}

Based on the target studies i.e. Antioxidant and Anti-inflammatory activities, four protein structures have been selected for target identification and validation. Three targets for antioxidant activity evaluation were selected based on the pathways which involve their active participation.

It has been shown in previous studies that many phytochemicals act as agonists and increase the activity of Superoxide dismutase (SOD), Glutathione peroxidase (GPX) and Catalase (CAT) [21]. Agonists of SOD, GPx and CAT may increase their activity and thus may overcome stress related ROS induction. Therefore, these three proteins SOD, GPX and CAT) have been selected as targets for antioxidant activity of phytochemicals. Threedimensional structures of these three target proteins have been retrieved from protein data bank (PDB) having PDB IDs: 1CB4 (Superoxide dismutase), 2CAG (Catalase) and 2P31 (Glutathione peroxidase).

Cyclooxygenase-2 (COX-2) is a well-known key protein which is generally targeted for its active participation in causing inflammation [22]. COX-2 is found to be strongly associated in almost all the inflammation-related symptoms. Common drugs like aspirin and ibuprofen (NSAIDS) which are used in the treatment of fever and pain are known inhibitors of COX-2. Many phytochemicals which show anti-inflammatory activity was found to inhibit COX-2 enzyme. Present target identification and validation work include COX-2 as a prime target to evaluate the anti-inflammatory activity of phytochemical library retrieved from selected five plants. The three-dimensional structure of the COX-2 enzyme has been retrieved from protein data bank (PDB) with PDB ID 1pxx.

\section{BINDING SITE IDENTIFICATION}

It is easy to determine the binding site when three-dimensional X-ray crystallized structure or target proteins or enzyme or receptor is available in PDB database in complex with the particular ligand. The binding site can also be determined in the case when a list of interacting amino acids are known. Present studies utilize published literature and molecular docking attempts to determine the binding site. A user defined coordinate system of ( $X, Y$ and $Z$ axes) can be easily used to map binding site on the target protein. Table 1 below summarizes three dimensional coordinates of the binding site of all four targeted proteins for antioxidant and anti-inflammatory activity evaluation of selected phytochemicals. 
Table 1. Target proteins and binding site coordinates used in molecular docking

\begin{tabular}{llll}
\hline S.N. & Target Protein/Enzymes & PDB ID & Binding Site Coordinates \\
\hline 1 & Superoxide dismutase (SOD) & 1CB4 & $\mathrm{X}=10.410, \mathrm{Y}=87.880, \mathrm{Y}=18.620$ \\
2 & Catalase (CAT) & 2CAG & $\mathrm{X}=58.380, \mathrm{Y}=19.080, \mathrm{Y}=18.300$ \\
3 & Glutathione peroxidase & 2P31 & $\mathrm{X}=-5.830, \mathrm{Y}=03.390, \mathrm{Y}=00.200$ \\
4 & Cyclooxigenase-2 (COX-2) & 1PXX & $\mathrm{X}=27.058, \mathrm{Y}=24.431, \mathrm{Y}=15.437$ \\
\hline
\end{tabular}

\section{DOCKING PARAMETERS}

Molegro Virtual Docker (MVD) has been used to perform screening of phytochemical library derived from five selected plants towards identification and validation of biological targets for antioxidant and anti-inflammatory activity [22]. MVD provides a user-friendly docking platform for flexible ligand docking keeping target protein structure rigid.

After importing and preparing protein structure, docking wizard provides a selection of docking option. Docking tab allows selection of a specific scoring function like Moldock Score and PLANTS score based on laws of molecular mechanics. Moldock GRID has been adopted for the present screening work. The grid resolution was fixed at 0.30 Angstrom. A search space known as a constraint of radius 15 Angstrom has been set around the binding site coordinate to include maximum amino acids surrounding the binding site. Ligands have been provided as a single external file. The binding site for different target proteins has been provided using user-defined option utilizing coordinate values as described in table 1 above.

\section{RESULTS AND DISCUSSION}

Molecular docking scores represent energy of interactions when a ligand occupies binding site at certain conformation. The conformation of the ligand in a particular pose is three-dimensional arrangement or orientation of its atoms or pharmacophoric groups in which the energy of interactions can be calculated. Negative molecular docking scores usually refer to more attractive interactions over repulsive interactions. Tables 2 produced below show highest ranked phytochemicals as ligands against target protein or enzyme structures.

Table 2. Target protein structure and best binding phytochemical identified in molecular docking.

\begin{tabular}{|c|c|c|c|c|c|c|}
\hline S.N. & Target Protein & $\begin{array}{l}\text { Phytochemical } \\
\text { Identified as } \\
\text { best ligand }\end{array}$ & $\begin{array}{l}\text { Mol } \\
\text { Code \& } \\
\text { Pose }\end{array}$ & $\begin{array}{l}\text { Selected } \\
\text { Pose }\end{array}$ & $\begin{array}{l}\text { Re-rank } \\
\text { Score }\end{array}$ & $\begin{array}{l}\mathrm{H}- \\
\text { bond }\end{array}$ \\
\hline 1 & $\begin{array}{l}\text { 1CB4: } \quad \text { Superoxide } \\
\text { Dismutase (SOD) }\end{array}$ & $\begin{array}{l}\text { Gliadin (Triticum } \\
\text { aestivum) }\end{array}$ & 17787981 & $\mathrm{I}$ & -111.036 & -5.329 \\
\hline 2 & $\begin{array}{l}\text { 2CAG: } \\
\text { (CAT) }\end{array}$ & $\begin{array}{l}\text { Terrestribisamide } \\
\text { (Triticum } \\
\text { aestivum) }\end{array}$ & 5321825 & I & -130.941 & -3.226 \\
\hline 3 & $\begin{array}{l}\text { 2P31: Glutathione } \\
\text { peroxidase (GPx) }\end{array}$ & $\begin{array}{l}\text { Tea Extract } \\
\text { (Punica } \\
\text { granatum) }\end{array}$ & 11980943 & 1 & -72.76 & -8.229 \\
\hline 4 & $\begin{array}{l}\text { 1PPX: } \\
\text { Cyclooxigenase-2 } \\
\text { (COX-2) }\end{array}$ & $\begin{array}{l}\text { 1,2,6- } \\
\text { Trigalloylglucose } \\
\text { (Punica } \\
\text { Granatum) }\end{array}$ & 440308 & III & -127.992 & $\overline{-}-176$ \\
\hline
\end{tabular}


Gliadin present in Triticum aestivum is found to have strong binding interactions (Table 2) with superoxide dismutase protein. Docking score confirms high binding affinity of Gliadin with supeoxidase Dismutase towards antioxidant activity. Tea Extract from Punica granatum successfully scored second highest binding score against SOD. Violaxanthin (Carica Papaya), Hesperidin (Citrus Limon) and Mutachrome (Carica Papaya) find third, fourth and fifth re-rank scores to bind SOD in binding site (Table 3). Therefore, best binding ligands have been selected based on their higher negative Re-rank scores. It is evident from docking scores shown in Table 2 that the phytochemicals derived from Triticum Aestivum, Carica Papaya and Citrus Limon may be promising agonists for Superoxide Dismutase (SOD).

Highest ranked pose out of five best poses (Conformations) of a ligand structure have been presented in table below.

Terrestribisamide derived from Triticum Aestivum is found to show highest Catalase (CAT) binding affinity in terms of Re-rank score (table 2). Vitamin P (Carica Papaya), Aurochrome (Carica Papaya), (1E,6E)-1-(4-hydroxy-3-methoxyphenyl)-7-(4hydroxyphenyl)hepta-1,6-diene-3,5-dione (Curcuma Longa) and Demethoxycurcumin (Curcuma Longa) have found corresponding re-ranks in molecular docking scores (Table 3).

Tea Extract from Punica Granatum has once again shown promising binding scores with Glutathione Peroxidase (GPx) (Table 2). Tea Extract has shown similar highest binding scores with Superoxidase Dismutase (SOD). This observation confirms Tea Extract derived from Punica Granatum can be responsible for its antioxidant activity against Superoxidase Dismutase (SOD) and Glutathione Peroxidase (GPx). Similarly, Vitamin P (Carica Papaya), 1,2,6-Trigalloylglucose (Punica Granatum), Hesperidin (Citurs Limon) and Protochlorophyllide (Triticum aestivum) have obtained similar re-rank scores against Glutathione Peroxidase (GPx) (table-3).

Pomegranate juice or extract is strongly related to its anti-inflammatory activity. Highest molecular docking scores of 1,2,6-Trigalloylglucose (Punica Granatum) against cyclooxigenase (COX-2) confirms its active role in anti-inflammatory activity offered by Pomegranate extract (Table 2). Hesperidin from Citrus Limon has also been found to offer COX-2 inhibition activity in present docking scores. Tea extract from pomegranate has also been found to possess a considerable COX-2 binding affinity. Riboflavin (Carica Papaya) and Terrestribisamide (Triticum aestivum) are found to bind COX-2 enzyme with comparable binding scores.

Selective top ranked poses of phytochemicals after screening against three antioxidant and one anti-inflammatory target proteins have been summarized and compared in the table 3 below. It is evident from the table 3 that many phytochemicals have been repeated to possess a considerable binding affinity against selected targets. Tea Extract (Punica Granatum) have been found to bind Superoxide Dismutase (SOD), Glutathione Peroxidase (GPx) and Cyclooxigenase-2 (COX-2) with higher docking scores. Similarly, Hesperidin (Citrus Limon) has shown repeated binding with Superoxide Dismutase (SOD) and Glutatione Peroxidase (GPx). 1,2,6-Trigalloylglucose (Punica Granatum) was found to interact strongly with Glutathione Peroxidase (GPx) and 
Cyclooxigenase-2 (COX-2). Vitamin P derived from Carica Papaya was found equally capable to bind Catalase (CAT) and Glutatione Peroxidase (GPx) (table 3).

Table 3. List of five best ranked phytochemicals identified as ligands against selected target proteins.

\begin{tabular}{|c|c|c|c|c|}
\hline S.N. & $\begin{array}{c}\text { Superoxide } \\
\text { Dismutase (SOD) }\end{array}$ & Catalase (CAT) & $\begin{array}{c}\text { Glutathione } \\
\text { peroxidase (GPx) }\end{array}$ & $\begin{array}{c}\text { Cyclooxigenase-2 } \\
\text { (COX-2) }\end{array}$ \\
\hline 1 & $\begin{array}{c}17787981 \\
\text { (Gliadin) } \\
\text { (Triticum aestivum) }\end{array}$ & $\begin{array}{c}5321825 \\
\text { (Terrestribisamide) } \\
\text { (Triticum aestivum) }\end{array}$ & $\begin{array}{c}11980943 \\
\text { Tea Extract } \\
\text { (Punica granatum) }\end{array}$ & $\begin{array}{c}440308 \\
1,2,6- \\
\text { Trigalloylglucose } \\
\text { (Punica Granatum) }\end{array}$ \\
\hline 2 & $\begin{array}{c}11980943 \\
\text { Tea Extract } \\
\text { (Punica Granatum) }\end{array}$ & $\begin{array}{c}24832108 \\
\text { Vitamin P } \\
\text { (Carica Papaya) }\end{array}$ & $\begin{array}{c}24832108 \\
\text { Vitamin P } \\
\text { (Carica papaya) }\end{array}$ & $\begin{array}{c}10621 \\
\text { Hesperidin } \\
\text { (Citrus Limon) }\end{array}$ \\
\hline 3 & $\begin{array}{c}448438 \\
\text { (Violaxanthin) Carica } \\
\text { Papaya }\end{array}$ & $\begin{array}{c}14192313 \\
\text { Aurochrome } \\
\text { (Carica Papaya) }\end{array}$ & $\begin{array}{c}440308 \\
1,2,6- \\
\text { Trigalloylglucose } \\
\text { (Punica Granatum) }\end{array}$ & $\begin{array}{c}11980943 \\
\text { Tea Extract } \\
\text { (Punica granatum) }\end{array}$ \\
\hline 4 & $\begin{array}{c}10621 \\
\text { Hesperidin } \\
\text { (Citurs Limon) }\end{array}$ & $\begin{array}{c}\text { 24939-17-1 } \\
\text { (1E,6E)-1-(4- } \\
\text { hydroxy-3- } \\
\text { methoxyphenyl)-7- } \\
(4- \\
\text { hydroxyphenyl)hep } \\
\text { ta-1,6-diene-3,5- } \\
\text { dione } \\
\text { (Curcuma Longa) }\end{array}$ & $\begin{array}{c}10621 \\
\text { Hesperidin } \\
\text { (Citurs Limon) }\end{array}$ & $\begin{array}{c}493570 \\
\text { Riboflavin } \\
\text { (Carica Papaya) }\end{array}$ \\
\hline 5 & $\begin{array}{c}5281246 \\
\text { (Mutatochrome) } \\
\text { Carica Papaya }\end{array}$ & $\begin{array}{c}5469424 \\
\text { Demethoxycurcumi } \\
n \\
\text { (Curcuma Longa) }\end{array}$ & $\begin{array}{c}439833 \\
\text { (Protochlorophyllide } \\
\text { ) } \\
\text { (Triticum aestivum) }\end{array}$ & $\begin{array}{c}5321825 \\
\text { (Terrestribisamide) } \\
\text { (Triticum aestivum) }\end{array}$ \\
\hline
\end{tabular}

A brief summary of $\mathrm{H}$-bonds formed by the highest ranked phytochemicals with target protein structures have been produced in figure 2. It is evident that oxygen atoms present in these phytochemical structure's backbone play crucial role in H-bond formation with target proteins. 3D conformations acquired by their structures in the binding sites of target proteins can provide basis to higher binding affinities. 


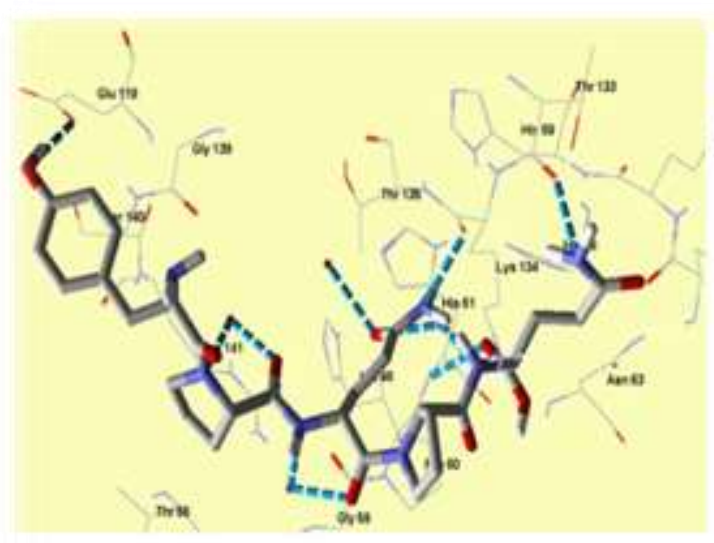

(17787981 with SOD)

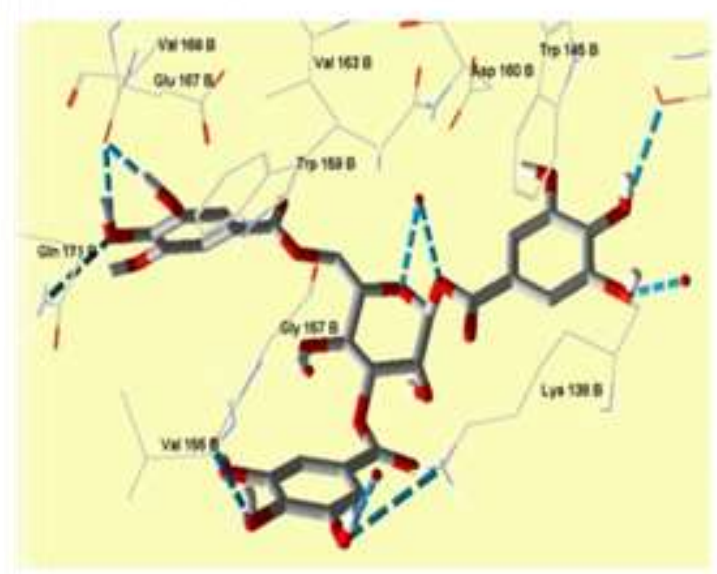

(11980943 with GPx)

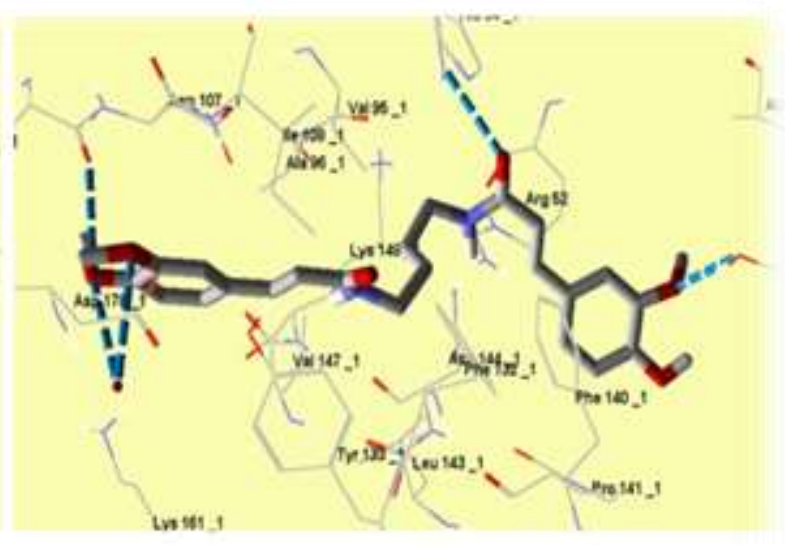

(5321825 with CAT)

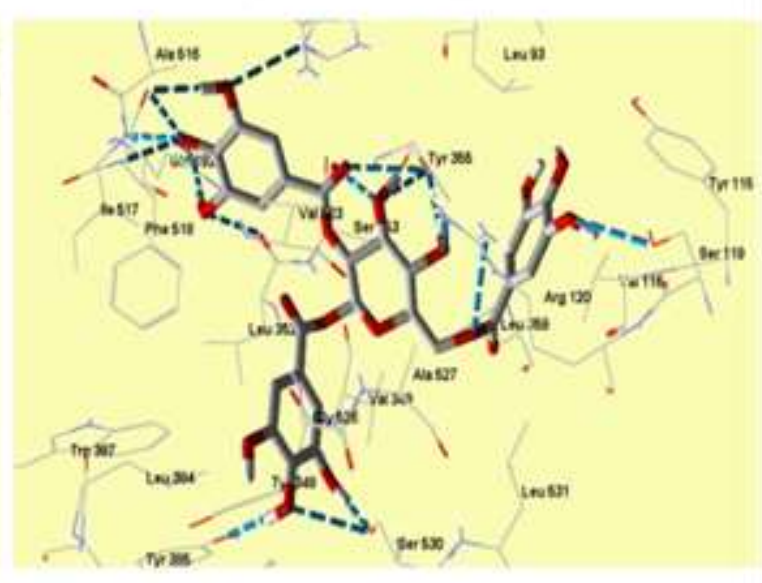

(440308 with COX-2)

Figure 2. H-bonds formed by the highest ranked phytochemicals with target protein structures.

$3 \mathrm{D}$ conformations and their alignment in the binding pockets of target proteins can be viewed using figure 3 below. Electrostatic surface on protein structures suggest various types of charges surrounding ligands in the binding pockets. Blue coloured surface shows presence of electropositive amino acids, red colour represents electronegative amino acids and white colour codes for electrically neutral amino acids. 


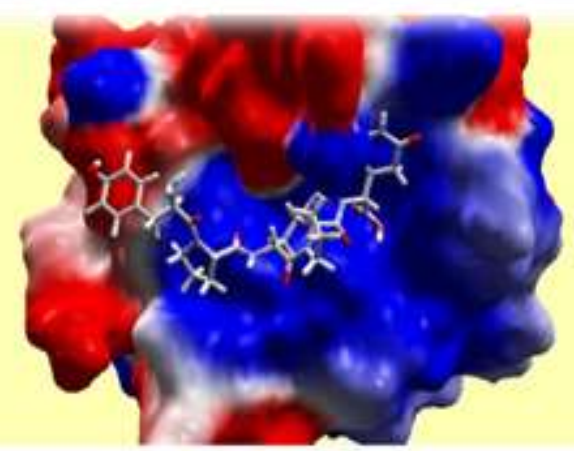

(17787981 with SOD)

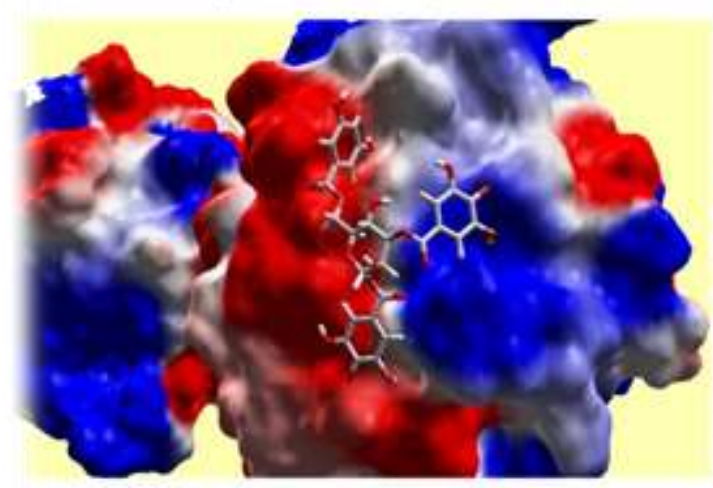

(11980943 with GPx)

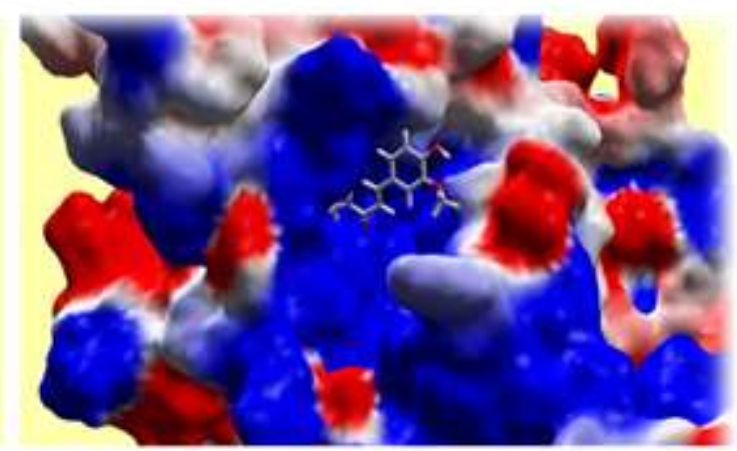

(5321825 with CAT)

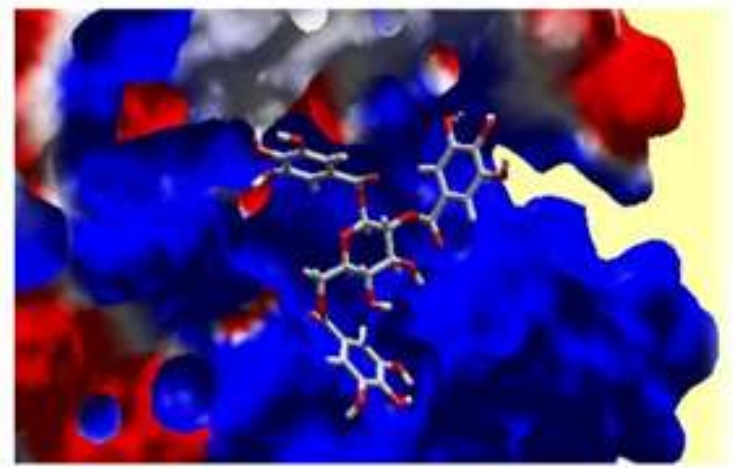

(440308 with COX-2)

Figure 3. Electrostatic surface illustrating binding sites of target proteins and alignment of 3D conformations of highest ranked phytochemicals as ligands.

\section{CONCLUSION}

IMPPAT which is a curated database has been employed for retrieving the list of phytochemicals from Carica papaya, Punica granatum, Curcuma longa, Dalbergia Sissoo, Citrus limon, Triticum aestivum. Computational screening was done against the small molecule library for the potent biological targets responsible for antioxidant and antiinflammatory activities. These were also validated for the same using Molecular docking. Binding affinities and docking scores revealed that certain phytochemicals (Tea extract, Hesperidin, Vitamin P, Terrestribisamide and 1,2,6-Trigalloylglucose from punica granatum, citrus limon, carica papaya, triticum aestivum and punica granatum respectively) were capable of binding protein targets (SOD, CAT and GPx). These may be responsible for agonist effect resultant into antioxidant activity. Similarly, COX-2 inhibition capacities were also visible in certain phytochemicals (Tea extract, Hesperidin, Terrestribisamide, 1,2,6-Trigalloylglucose and riboflavin from punica granatum, citrus limon, carica papaya, triticum aestivum and carica papaya respectively). These identified phytochemicals should be further evaluated for their target-based antioxidant and antiinflammatory activities in-vitro.

Funding: This research received no external funding.

Conflicts of Interest: The authors declare no conflict of interest.

\section{REFERENCES}

1. Yogiraj V, Goyal PK, Chauhan CS, Goyal A. and Vyas, B. Carica papaya Linn: An Overview. Int J Herb Med. 2014; 2:1-8. 
2. Raaman N. Thin Layer Chromatographic Analysis and Antioxidant Activities of Methanol Extract of Leaves of Carica papaya L. IJAPBC. 2015;4.

3. Anjum V, Ansari SH, Naquvi KJ, Arora P. and Ahmad, A. Development of quality standards of Carica papaya Linn. Leaves. Sch Res Lib. 2013; 5:370-6.

4. Del Rio JA, Fuster MD, G'omez P, Porras I, Garcia-Lidon A, Ortuno A. Citrus limon: A source of flavonoids of pharmaceutical interest. Food Chemistry. 2004; 84:457-61.

5. Peterson JJ, Beecher GR, Bhagwat SA, Dwyer JT, Gebhardt SE, Haytowitz DB, Holden JM. Flavanones in grapefruit, lemons, and limes: A compilation and review of the data from the analytical literature. J. Food Compos Anal. 2006; 19:74-80.

6. Ikoma Y, Komatsu A, Kita M, Ogawa K, Omura M, Yano M, Moriguchi T. Expression of a phytoene synthase gene and characteristic carotenoid accumulation during citrus fruit development. Physiologia Plantarum. 2001; 111:232-8.

7. Aggarwal BB, Kumar A, Bharti AC. Anticancer potential of curcumin: preclinical and clinical studies. Anticancer Research. 2003; 23:363-98.

8. Gounder DK, Lingmallu J. Comparison of chemical composition and antioxidant potential of volatile oil from fresh, dried and cured turmeric (Curcuma longa) rhizomes. Industrial Crops and Products. 2012; 38:124-31.

9. Maheshwari RK, Singh AK, Gaddipati J, Srimal RC. Multiple biological activities of curcumin: A short review. Life Science. 2006; 78:2081-7.

10. Anonymous. Wealth of India, vol. VIII. Publication and Information Directorate (CSIR), New Delhi. 1969;317-324.

11. Prashanth D, Asha MK. and Amit, A. Antibacterial activity of Punica granatum. Fitoterapia $2001 ; 72: 171-3$.

12. Dutta BK, Rahman I, Das TK. Antifungal activity of Indian plant extracts. Mycoses. 1998; 41:535-6.

13. Gharzouli K, Khennouf S, Amira S, Gharzouli A. Effects of aqueous extracts from Quercus ilex L. root bark, Punica granatum L. fruit peel and Artemisia herba-alba Asso leaves on ethanolinduced gastric damage in rats. Phytother Res. 1999; 13:42-5.

14. Tirgar PR, Thumber BL. and Desai, T.R. Isolation characterization and Biologocical evaluation of iron chelator from Triticum aestivum (Wheatgrass). Int J Pharm biosci. 2011; 2:288-96.

15. Marawaha RK, Bansal D, Kaur S, Trehan A. Wheatgrass juice reduces transfusion requirement in patients with thalassemia major: a pilot study. Indian Pediatr. 2004; 1:716-20.

16. Bharath M, Tulasi E, Sudharkar K. and Eswaraiah, M. A review on Dalbergia sisso- an important medicinal plant. International journal of Research in Pharmacy and Chemistry. 2013; 3:384-8.

17. Sau S, Handral M. A review on recent developments in the research area of Dalbergia sissoo. International Journal of Pharmaceutical and Biological Archives. 2014; 5:1-8.

18. Reddy RVN, Reddy NP, Khalivulla SI, Reddy MVB, Gunasekar D, Blond A, et al. O-prenylated flavonoids from Dalbergia sissoo. Phytochemistry Letters. 2008; 1:23-6.

19. Cesquini M, Torsoni MA, Stoppa GR, Ogo SH. T-BOOH-induced oxidative damage in sickle red blood cells and the role of flavonoids. Biomedicine and Pharmacotherapy. 2003; 57:124-9. 
20. Daisy P, Suveena S, and R. Cecily Rosemary L. Target level analysis of antioxidant activity of costunolide and eremanthin isolated from costus speciosus. Asian $\mathrm{J}$ Pharm Clin Res. 2012;5(4):32-5.

21. Shailasree S. Cyclooxygenase-2, Drug Target for Anti-Inflammatory Bioactives from Natural Sources. Molecular Enzymology and Drug Targets. 2016;2(2):1.

22. Schulz-Gasch T. and Stahl M. Scoring Functions for Protein-ligand Interactions: A Critical Perspective. Drug Discovery Today: Technologies. 2004; 1:231-9.

(c) 2018 by the authors. Submitted for possible open access publication under the terms and conditions of the Creative Commons Attribution (CC BY NC) license (https://creativecommons.org/licenses/by-nc/4.0/). 